\title{
Visual 'Bildung' between Iconoclasm and Idolatry
}

\author{
Yvonne Fritze, Geir Haugsbakk \& Yngve Nordkvelle
}

\begin{abstract}
The point of departure for this article is 'the visual turn', the proclaimed need for specific competencies, and furthermore the lack of clarity in the concepts and the lack of research that accompany the use of images. Terms like 'visual literacy' and "visual competence' are compared with a concept of visual 'Bildung'. 'Bildung' is presented as a concept that clearly goes beyond qualifications and a dominant market-oriented comprehension of competence. In its origin, 'Bildung' has obvious references to 'image', and it may also offer interesting new perspectives in the battle between words and images that has taken place throughout history and is a background to today's situation. 'Bildung' opens up an interesting path between iconoclasm and idolatry. The article proclaims an urgent need for a visual and reflective 'Bildung', because images are closely related to the world in which we live today.
\end{abstract}

Keywords: visual turn, visual Bildung, reflective Bildung, competence, literacy, complexity

\section{Introduction}

Communication is increasingly taking place through images. This is sometimes referred to as 'the visual turn', and it has been claimed that we live in a visual culture that calls for specific competencies (Buhl \& Flensborg, 2011). One important aspect of the current situation is the lack of research to accompany the growing use of images, and this is very evident in the unclear use of concepts. The term 'visual literacy' has been standard in American education for 150 years (Elkins, 2008), while new terms such as 'visual competence', 'visual language' and 'visual culture' have been introduced. In what follows we compare these terms with a concept of 'Bildung', in order to establish the extent to which it is meaningful to talk about 'visual Bildung' as an important element in the ideals of the 'Bildung' of the future. A consideration of the concept of 'Bildung' may also offer interesting new perspectives on the battle between words and images that has taken place throughout history and is a background to today's situation. Furthermore, it opens up a path between iconoclasm and idolatry, as W. J. T. Mitchell (2005) has argued, which is an important challenge within media research.

The main aim of this article is to suggest a framework for reflecting on the position and use of images in education today, something that cannot be done without considering the relationship between words and images. We want to build an argument for how the use of images can be more closely connected to a central discourse in the field of media education, namely 'Bildung'. 


\section{A Critical Examination of Contemporary Interpretations}

This is in several ways challenging, and the line of argument we try to establish is critical of contemporary interpretations of the meaning and focus of media education. We are aware that some writers think the notion of Bildung is conservative and impractical and would rather use terms like 'competencies' or 'literacies'. We will argue that such terms either fail to consider the normative dimension of pedagogy, or carry too many connotations with text and its metaphors. The inherent logocentrism of discourses on literacy encourages us to look more closely for a theory of the pedagogical foundation of the visual that goes beyond the literary.

We believe that the established academic discourses regarding images are often unclear and contradictory and we suggest that, as a result, they affirm a logocentric tendency. We will argue that logocentric ideas about Bildung fail to capture vital historical dimensions of the value of the visual, and indirectly confirm Enlightenment ideals and fears of the visual as seductive and dangerous. We hope to make a successful argument that the visual opens up the question of Bildung to the insecure and inconclusive, which is an interpretation more in line with more recent philosophical discourses about the social condition.

When visuals have been taught in school, the curriculum has been set out as a negotiation between critical distance and fascination. On the one hand media messages have been critically examined, and on the other the student's own production of media material has been met with enthusiasm. To some extent this might be seen as reflecting the positions of iconoclasm and idolatry. This leads to another crucial point that we emphasise in this paper, namely the lack of historical perspectives concerning the relationships between words and images and how words and images may be seen as related to societal change. Logocentrism has been an important part of Western thinking since the Enlightenment, while visuals, often regarded as moral threats to modernity, are more related to today's society. The associated openness and ambiguity of images are closely linked to the unique characteristics of 'post-modernity'.

The article is the result of a reflective process in which we tried to deal with challenges of this kind. Our conclusions need to be preliminary, but we hope that the article will suggest a meaningful direction for further reflections and research. The examples used to illustrate the historic relationships between words and images are selected for the purpose of highlighting striking differences, rather than to present a framework that pretends to describe coherent lines of development. We have given priority to theoretical perspectives that we have found useful in illuminating the characteristics of Bildung and its relationship to visuals, in the theoretical meeting between education and media studies. Consequently, some media theorists associated with important contributions in the domain of media and visuals are omitted.

The article contains three major parts. In the first part the concept of Bildung is introduced along with a basic understanding of Bildung that underpins the arguments and reflections put forward in the article. The history of Bildung is then related to the 'battle' between words and images over a long historical perspective. The second part of the article goes deeper into the lack of clarity in the discourses regarding visuals, and explores how research associated with social semiotics and multimodality has failed to give the various modalities a satisfactory equivalence. In the last part an alternative approach to images is presented, proclaiming the need for a visual and reflective Bildung. 


\section{The Unique Characteristics of Bildung}

The concept of 'Bildung' has been used for centuries in German and Nordic countries. In Norwegian and Danish the term is 'dannelse', and in Swedish it is 'bildning'. 'Bildung' may be regarded as a complex and challenging concept, and perhaps also as a normative concept that is associated with a set of traditional ideals and universal values. No such concept exists in the English-speaking world, and the word notoriously defies translation. 'Bildung' has on occasion been translated as 'personal identity building' or 'existential competence' (Elf, 2009). Most often it is rendered as 'education' or 'formation' (Nohl, 2007), or the original German word, 'Bildung', is maintained in the English context, as is the case in this article.

An extended consideration of the term Bildung permits us to highlight important aspects of concepts and phenomena in current debates concerning new media, such as 'competence' and 'literacy', that have been more widely addressed. Furthermore, in order to pinpoint the unique characteristics of Bildung compared to the prevalent understanding of competence and literacy, we have found it most useful to promote Bildung as a separate phenomenon and as a concept on its own. To a large extent 'competence' in common parlance is associated with instrumentalism and is given a clear market orientation, since it has become a key concept in the planning documents of the European Union and the Organisation for Economic Co-operation and Development (OECD). 'Literacy' is characterised by the influence of traditional textual metaphors as well as expectations of linearity, coherence and clarity.

An introduction to Bildung in this article implies a non-normative understanding of Bildung, such as has been emphasised by the Norwegian educational philosopher Lars Løvlie, in his concept of 'technocultural Bildung'. This implies 'hypertransformation' as part of constantly being online (Løvlie, 2003). Likewise, the German educational philosopher Arnd-Michael Nohl describes 'media-bildung' as a 'process of transformation": "the people concerned undergo fundamental changes in their attitude towards the subject-matter covered by media and/or the media itself" (Nohl, 2007, p. 418). Moreover, the Danish media theorist Lars Qvortrup (2004) underlines the fluidity of the phenomenon in his term 'reflective Bildung', to which we propose to return later. Such approaches have played only a minor role within Nordic research into media and/ or media pedagogy, but for some researchers Bildung has been an important touchstone (Drotner, 2003; Erstad, 2005; Østerud, 2007).

While traditional notions of Bildung are mostly associated with words and written texts, the origin of the concept contains obvious references to 'image', as indicated by the German construction 'Bild-ung'. This connection has been re-established in recent years. A report published by the Norwegian Bildung Committee ('Dannelsesutvalget for høyere utdanning') (2009) emphasises the ways in which the concept of 'visual Bildung' has been integrated into the programmes offered by elite universities in the US. However, this is problematic. First, since the primary focus has generally been on skills and competence, the different aspects inherent in the term Bildung are given little prominence in the dominant discourse. Secondly, when Bildung is thematised, discussion has largely revolved around the traditional ideals of Bildung, which are based on the written word and, to some degree, are inimical to the visual. This is far from satisfactory, and such a slant prevents us from viewing the development of visual expression 
and visual Bildung within a longer historical perspective in which the battle between words and images features prominently.

In what follows, we wish to focus on the visual elements, while emphasising the importance of the relationship between images and Bildung. Further, it is necessary to establish a more suitable framework in which we can reflect upon the relationship between words and images and delve more deeply into the premises in order to allow a more balanced approach to emerge. We believe that by focusing on Bildung new perspectives may be opened up for enquiry. Our view is that such an approach may also be relevant to several other topics in ongoing debates within communication and media research. These include the impact of new media upon the development of identity (Østerud, 2007), the 'complexities of self-presentation' among young people today (Storsul, 2014), the 'reductionist approaches' in the prevalent political discourses (Verdegem \& Fuchs, 2013) and ethical and social issues arising from the new forms of communication (Enghel \& Wilkins, 2012; Odame \& Oram, 2012). However, we realise that our approach is part of a complex matter.

\section{The Complexity of Words and Images}

W. J. T. Mitchell has made a significant contribution to a differentiated and problematised understanding of images and new media (Mitchell, 2010). He has also drawn a distinction between 'image' and 'picture'. One of the important aspects of this differentiation is that in some contexts 'picture' may have a more obvious concrete meaning distinguishing it from a virtual or abstract comprehension of 'image'. Mitchell approves the common assumption of the dominance of visual media, adding, however, that images are by no means 'everything', and that there is a reality outside images. He also draws attention to the fact that many of the forces affecting people's quotidian existence are invisible and that scepticism about images is increasingly evident (McNamara, 1996).

The main aim of Mitchell's research into images and visual media has been to carve out a compromise between 'iconoclasm' and 'idolatry' or idolisation (Mitchell, 2005). In the discussions on theoretical media in the 1990s, Mitchell, in an interview made by Andrew McNamara (1996), indicated that the latter position was rooted in the postmodern Baudrillardian version of the image. The former went back to Adorno's desire to maintain an aesthetic judgment, and to be able to distinguish between art and non-art, good and bad. We support Mitchell's approach, as well as his description of the relationship between words and images - namely what, with reference to Foucault, he calls the 'sayable' and the 'seeable'. Mitchell presents this as a "fundamental dialectic of cognition and perception". However, the boundaries are somewhat blurred. Words and images often concern 'mixed media'. To some extent, we are bound to 'read' an image and treat it as text and, vice versa, to 'see' the verbal, treating it as an image, but an image cannot be 'cashed in' for words. This is a consideration that has inspired part of our approach, which has also been informed by the way Mitchell regards images and visuality as 'a specific point of irritation in contemporary theory, an unsolved problem or anomaly' (McNamara, 1996). Our point of departure for addressing this challenge is Bildung as a concept and phenomenon. 


\section{The History of Bildung - A Battle between Words and Images}

'Bild'-ung refers to 'image', as mentioned above. The term originated in the German/ Dutch language of the eighth century and means 'model' or 'pattern' (Müller, 2007). New connotations, some of which leaned towards our concept of Bildung, were added in German in the eighteenth century. In Swedish, the visual element of Bildung is retained in the word 'bild'-ning. Lars Løvlie links the Norwegian word 'bildet' (image) to the cultural-historical phenomenon of 'Imago Dei' - created in God's image - in the Christian tradition. Agreeing with Løvlie, Marion G. Müller, a German professor of visual studies, argues that the image has a certain primacy in the debate on the genealogy of the Bildung concept, saying, 'As an advocate of visual research I cannot help but argue that this is not accidental, that this subtle visual connotation of 'Bildung' reveals that: "The learning experience is at its core a visual experience" (Müller, 2007, p. 10), and the visual experience has a first-ranking position in the process of Bildung. The Swiss professor of media pedagogy, Christian Doelker, has argued that, from a historical perspective, the image predates signs and texts, "In the beginning, there was the image", "[...] writing was preceded by the petroglyph, articulated language by the mimic expression, rational thought by the mythical belief" (Doelker, quoted by Hug, 2011, p. 2). Doelker implies that our fascination with, and interest in, the pictorial sits 'deeper' in our mentality than anything associated with writing.

In the Greek ideas of Bildung, the 'model' was the experienced older warrior, who kept his favourites closely attached to him - an association that was also sexual in nature, as we learn from the French educational historian Marrou (1956). It was the teacher's dream and ideal to recreate and immortalise himself through his pupil. As the role model, the nurturing teacher was transformed in the early Christian Church and in the writings of Bishop Clemens of Alexandria; God is described as the Pedagogue, the Teacher (Myhre, 1967). To be created in God's or the good teacher's image is rooted in the visual imagination that belongs to our conception of the world. While Plato uses cave metaphors, Christ uses his idealised parables. In Müller's etymological archaeology, terms such as 'pictorial magic' and 'miracle' persist as disturbing elements, but they also help to maintain a tension between the mental aspect of 'being like' and 'depiction' as a material event.

In the Bible, the Gospel of St. John says that: "In the beginning was the Word", although considerable research indicates that Man's first cognitive utterances were visual in nature, e.g. the symbolic communication of cave paintings (Hertzberg, 2003). However, the importance of oration was affirmed in Greek and Roman rhetoric - which was always memorised from text - as an important tool of power, and it can therefore be seen that a word-based ('logocentric') model took hold in the thinking of the Latin West. The German art historian Horst Bredekamp claims that there is "[...] an anti-visual bias in Western thinking" (quoted by Müller, 2007, p. 24). Michelangelo was said to complain that poets and authors always received more recognition for their work than artists. The mental processing of texts certainly demanded a more abstract form of mental activity, although the art of memory was associated with images long after written culture made its breakthrough. In her book, The Art of Memory, Yates (1966) notes that, in the Renaissance, memory was associated with visual encoding and that Simonides allegedly managed to rescue his guests from his collapsed house by remembering where each one was seated around the table. Hence, the 'picture' that emerges when we trace the historical background of visual Bildung is a complex one. 
A paradox here is that we also find the source of the forbidden image in the Old Testament as practised in the Jewish, Christian and Muslim traditions. According to Gundersen (2006, p. 1) the Second Commandment in the Law of Moses says: "Thou shalt not make unto thee any graven image, or any likeness of anything that is in heaven above, or that is in the earth beneath, or that is in the water under the earth". This marks the beginning of the 'battle' between the words and the images. While Semitic hostility to images was carried over into the Muslim tradition, the Second Commandment, which forbade images, was deleted from the Catholic catechism and the last commandment divided into two. The battle between word and image can be seen as a centuries-old return match: as in the eighth century a dispute erupted in the Byzantine Empire between the so-called iconoclasts (those against the use of images) and the iconodules (those in favour of images), concerning the depiction of Christ and other holy personages. The iconoclasts regarded images of Christ as blasphemous, concerned as they were about the appeal of images to idolatry, with countless examples of ecclesiastical paintings being destroyed or painted over during the Iconoclastic Period. For the century or so that this first wave of iconoclasm lasted, the cross was the only motif permitted (Gundersen, 2006).

Berg Eriksen (1995) reminds us that the Catholic Church was rich in imagery depicting Man's damnation and salvation. Here, images were created to impart a uniform and theologically determined message, whereas depictions of purgatory were a constant reminder to the congregation to adhere to the straight and narrow. When the Protestants went on to purge their churches of such images, the artist's links with the Church were severed. Consequently, the image was 'liberated' too, becoming the object of interpretation and association. As a result, the 'enlightened classes' could now begin to admire art as an expression of humanity and fellowship. Berg Eriksen points out that the image's unequivocal nature arises from its presentation of evidence - "yes, that's what it's like" - with a close connection being established between what is shown and the observer's gaze. Discrepancies in interpretation occur because people cannot agree on what is evinced; the fact that images are evidence of something remains a firm conviction, nonetheless. Although we now consider ourselves to be modern-minded, we continue to kiss pictures of our nearest and dearest. This act in and of itself is absurd and reminds us of the association between the person kissing the picture and the depicted object, which is invested with mystical qualities (Berg Eriksen, 1995). The longing inherent in the look, as well as the pleasure in the act of looking, are both connected to such primary - or mystical - aspects (Mulvey, 1999).

Images have credibility insofar as they represent real people, situations and events that arouse associations, prompt unexpected thoughts or draw one's thoughts in directions that are not necessarily predetermined, unlike text that has an intended purpose. The aim of the text in information-related contexts is to appeal to a sequential form of comprehension, while an image stimulates associative brain function (Müller, 2007). This rivalry between text and image is also naturally felt in schools and education contexts in which reading and writing are of paramount importance, whereas images, art and crafts are either regarded as diversions or are relegated to the domain of vocational education. Thus Bildung as promulgated at school is primarily a textual activity that finds its ultimate expression in academic certificates that qualify students for university admission ('examen artium') (Johnsen, 1997). While Bildung has been translated into 
Norwegian with varying degrees of success, it is not just by chance that the English word 'literacy' is faithful to words and reading as its basic metaphor.

\section{The Image as a Challenge in Educational Discourse}

The logocentric tendency in Western thinking is affirmed in educational discourse: word and text have always been the core elements. While written presentations are associated with totality and coherence, images are generally considered to be potentially threatening and morally subversive. These perspectives were reflected in the clear division in school curricula and action plans in Norway during the 1990s between computers on the one hand and traditional mass media on the other. New information and communication technology was lauded, and at the core of this lay a generally optimistic view of technology that was historically grounded. Computer technology was made compatible with the established ideals of Bildung, whereas film and television were regarded as having a divisive function (Haugsbakk, 2010). This resulted in a shaky basis for acquiring an understanding of the more recent developments in technology and the media, in which many of the uniquely new and interesting elements actually came into being in the interface between computers and the mass media. In short, we can say that the evaluation of new technology and media in school planning documents was characterised by outdated ideals of Bildung and narrow, skills-related perspectives. The opposition between word and image was apparently harmonised away with the introduction of the concept of composite texts into the core curriculum for Norwegian language and literature in 2006. This is based on an expanded concept of 'text' that includes writing, sound and images. In other words, pictures can be brought in from the cold as long as they can be perceived as texts.

A concerted effort to reconcile Bildung and skills-related perspectives has been made by leading educational research communities, with the solution involving, in the first instance, the establishment of an expanded concept of competence (ITU, 2003). As a result, aspects of Bildung have become an integral part of the debate, while they are also associated with interesting contributions, particularly from the British literacy tradition (Erstad, 2005). We take issue with this, first because it has the effect of toning down or erasing the unique differences between Bildung and competence, and secondly because it can be interpreted as a situationally-determined adaptation to international trends. We argue that during the last decade the concept of Bildung has been forced into a rhetorical straightjacket emanating from supranational agencies, particularly the EU and the OECD. In our view, this has resulted in a market-adapted notion, with Bildung being subsumed into the 'competence' sack. Thus it is our contention that the concept of Bildung would benefit from retaining its restless and critical character, with its goad pricking the market and supranationality. We further believe that an approach consisting in the recycling of the ideals of Bildung in an attempt to patch over any antithetic and difficult aspects is a deficient one.

The challenging aspects of this approach are well illustrated by Peter Kemp, who has pointed out that the broader term Bildung is ethical in intent, whereas education aims at competence. Today, education is needed to foster an understanding of the questions of modern society, and without knowledge there is no Bildung (Kemp, 2006, p. 168). The education system must therefore contribute to Bildung through a wide range of competencies, including the visual (Hagtvedt, 2009, p. 8). 


\section{Technocultural Bildung and The Significance of the Image}

In the article mentioned above, Løvlie makes important contributions to the discussion of the relationship between competence and Bildung. He argues that Bildung requires a radical and significant re-think, and he includes the visual in this requirement. The basic theme in the classical debate on Bildung is presented as the opposition between the individual and the general (Løvlie, 2003). Bildung occurs in the refinement of this relationship between the self and culture, although in technoculture the self and cultures are transmuted into more fluid phenomena. The neohumanists presented Bildung as "the moral and cultural self-formation of man with the aim of realising the timeless ideality of the person and of bringing an inner freedom to his way of existence" (Shelsky, quoted in Løvlie, 2002, p. 467). Løvlie explores the incomplete nature of Bildung and how we ceaselessly relate ourselves to different positions in networks that allow different sides of ourselves to be played out. 'Bildung' arises in unstable and indeterminate situations in which culture and the self are cast into transformative processes, with the outcome becoming more uncertain and the risk increasing that the stream will flow in unexpected directions and unforeseen ways. In the interface between the subject and the world, both a cool head and passion are needed, as well as self-reflectivity and worldly wisdom, because transformations take place at such speed. It is possible to define Bildung as a reflection of our capacity for change, or of our aptitude for transformation. Indeed, classical Bildung has been measured in terms of its transformative capacity, although technocultural Bildung must be measured by its hypertransformativity. According to Løvlie, "hypertransformation means being online, living at the edge and experiencing restlessness and the dimensionless" (2003, p. 354).

In his article 'The Promise of Bildung', Løvlie (2002) expands his view on Bildung. He makes a convincing case for the need to trace the development of visual expression in a long historical perspective, and envisages three changes or epochs that are associated with different views on Bildung. The first change occurred in the sixteenth century when 'the art image" replaced 'the religious cult image', an image in which the artist takes God's place. In many ways this change can be said to have started with the Protestants' attack on all symbols that could be identified with the influence of the Catholic Church. They reinstated God's authority directly through the text, although this 'detheologisation' paved the way for seeing the artist in the work. The next significant change in the function of the visual came about with the advent of photography in the first half of the nineteenth century. Løvlie pays close attention to photography, and through an analysis of a text by Roland Barthes on looking at family photographs again, he postulates that the associative power of the picture tells us more about the challenge of Bildung than the neohumanist 'telos of perfection' (Løvlie, 2002, p. 478). Of interest, however, is how, precisely, the photograph represents an authentic reference - a reference that is later lost with the advent of the postmodern age, which constitutes a transition that corresponds to a change in the ideals of Bildung: "With the loss of the referent, the image loses its validating power and ethical significance, which seems to spell the end of Bildung in its classical sense". This ending coincides with the transition to the third epoch in the development of the visual from the latter part of the twentieth century, which is marked by an explosion of visual media. This is a period that is also characterised by scepticism about the image and by the presumption that the image has in some way been manipulated: "[...] realism has lost out to art and artifice" (Løvlie, 2002, pp. 471-472). 
It is no longer possible to adhere to special interpretations or realities, as Bildung or 'self-Bildung' takes place through the interface of screens in which we present ourselves through words and pictures and see others from an ever-shifting viewpoint.

\section{Social Semiotics and Multimodality - Some Critical Perspectives}

As an antidote to the somewhat commonplace use of 'reading' as a metaphor, it is worthwhile to put the concepts of social semiotics and multimodality under a critical lens. Social semiotics theorists, such as Günther Kress, use expressions like 'reading images'; therefore, the use of phrases such as 'visual literacy' is reasonable. The analogy is both obvious and incomplete, and the point of visual competence can easily elude us; according to Müller, “... images are not read, they are seen” (Müller, 2007, p. 14). Müller argues that the visual field has an altogether different origin from the fields of reading and writing. While texts strive for clarity, images are associative. Thus, reading is linked to identifying the unambiguous, whereas seeing is conditional on the open and ambiguous.

Hence, the phenomenon of literacy has a historical background in the 'modernisation' process, in which the written language has played the role of a filter for social selection, in addition to being a tool for discipline and mind control (Hultqvist \& Petersson, 1995). The rediscovery of reading ability in our time is particularly associated with the decade of development, as the UN called the 1960s, and its drive towards literacy. An important role in associating freedom from poverty with literacy and social rebellion is attributed to the Christian existentialist Paolo Freire, who inspired socially-conscious movements all over the world to take the initiative in promoting the teaching of reading to the poor and neglected. Jewitt (2008) points out that media literacy and 'multi-literacies' originated from Freire-inspired specialists, who wished to capture the complexity that children experience in encountering so many forms of visual expression while continuously 'reading' them in the classroom or other situations. Within this tradition, to be 'literate' means to master 'the art of reading', which includes the reading of images, facial expressions, texts and textual forms that extend to the classroom, architecture and moods. By 'visual literacy' we mean the ability to master and interpret all these texts competently enough to discern other peoples' intentions and then to use these visual means to counteract or argue against any violation, or exploit the positive effects of these forms of expression to the full. This appropriation of the concept of literacy may therefore seem to have a primarily socio-political basis, in the same way as liberation from oppression still has positive political values, although scientifically speaking it seems more confining than 'liberating' as far as understanding visuality is concerned.

Like Müller, Hug (2011) is deeply sceptical about this appropriation of textual metaphors, and argues that the constant addition of new 'literacies' such as environmental literacy, family literacy, sexual literacy, etc. is decidedly unfruitful. Building on Kress's work, Hug argues that we should seek a more basic pragmatic structure in what he calls a collective set of skills: "literacy, numeracy and picturacy". Within Anglophone academia, the fields of visual culture and visual studies have appeared as established scientific disciplines, although literacy studies continue to dominate in the pedagogical field.

Widespread modalities of the 'universal pragmatic' connection of literacy to various phenomena, such as those outlined above, all too easily hide the fact that letters, words, 
images, numerals, formulas, etc. are linked with various forms of meaning creation, significance attribution and knowledge building (Hug, 2011, p. 8).

In line with Müller and Hug, we can therefore say that grounds exist for a dualpronged approach to the academic tradition, rooted in multimodality, that largely originates in the work of Günther Kress, Theo van Leeuven and socio-semiotics. One major source is the influence of text-based approaches to multimodality, which most clearly manifests itself in the heritage of the Australian linguist M. A. K. Halliday (Engebretsen, 2010). It was obvious that Kress and van Leeuwen were aware of this tendency, and they commented on the dominant position that writing has enjoyed as a semiotic resource in school education at the cost of visual and other forms of expression (Slot, 2007). When modality theories operate by means of an elaborated concept of text without being basically linked to verbal language, and yet are independent of determined sign systems or semiotic resources, certain dilemmas are bound to arise (Kress, 2003). A fixed base in traditional text understandings is a certain natural concomitant, reflected in its use of concepts and metaphors, since the textual concept remains central, even though it is made clear that this is an elaborated concept of text that also includes images, colours, music, etc. As noted, Kress himself adopts the concept of 'reading images' that has been widely implemented in the new curriculum in Norway through the collective term 'composite texts', which corresponds largely to the concept of multimodality; secondly, the curriculum's selection of texts is not as varied as the aim of working with composite texts leads us to believe (Løvland, 2007).

Thus, the tradition associated with multimodality has been faced with a fundamental challenge in giving the various modalities a satisfactory equivalence. At all events, it would be useful to choose one type of modality as a basis or perspective in order to demonstrate more clearly the unique characteristics of the different modalities, and to show how these are both conditioned by today's society, and yet change it. Working with modality also appears to have had a harmonising and partially levelling effect, which is due to its having been largely associated with the work on an elaborated concept of text that has been pursued in Norwegian schools since at least the 1970s. In such a context, the determining difference today will primarily be the entirely new possibilities for multimodality, as well as the new text formats offered by new technology and media (Schwebs, 2009). By contrast, the research and development associated with multimodality have contributed important corrections to academic traditions that were previously limited to verbal language, and have yielded significant insights into new forms of expression based on other modalities, including the visual. A great deal of attention has been lavished on the interplay between different kinds of modalities (Løvland, 2011, Tønnessen, 2010). Liestøl, however, points out that even though multimodality has given rise to new forms of interplay, digitalisation leads to new opposing distinctions, such as 'auditive' - 'visual' and 'static' - 'dynamic'. He considers these conflicts to be more important in today's society than the traditional opposition between word and image. Furthermore, Liestøl states that in order to exploit the potential of communicative resources fully, it is necessary to overcome all of these types of opposition (Liestøl, 2006). In this way, interesting contributions have been made through the development of theory, as well as through the analysis and discussion of examples of texts (Løvland, 2007). This has been beneficial to the work being done in schools towards implementing "composite texts". 


\section{Visual Competence and Visual Bildung - A Complex and Interesting Relationship}

There is a line that runs from the cave paintings of prehistoric times to the vast array of video clips on YouTube in the digital age. In purely qualitative terms, there is no doubt that there has been an exponential increase in the production, dissemination and use of visual material. On the other hand, the sense of changing directions and paradigm shifts can arouse unhappy associations, as it is natural to focus exclusively on the most recent Internet-based developments. Nevertheless, the result is not only that the significance of developments in the mass media in the 1980s will be overlooked, but also that the key role that the visual has always played in human communication becomes even more likely to be ignored. Thus, the image can also constitute an important connection between the past and the present (Løvlie, 2002), in which the perceptions of a change towards the visual are stimulated by the prominent position modern society has attributed to textual presentations, which have become synonymous with all-inclusiveness and connectivity. Against this background, we have seen many examples of how images have been experienced as threatening and perhaps also as morally subversive.

The sense of a change towards the visual is bolstered by both the increased importance of the image and changes in how visual communication takes place. The German sociologist Marion G. Müller chooses to stress the latter, pointing out how social and political factors at the beginning of the new century appeared to be highly complex, "but also highly visual in appearance" (Müller, 2008, p. 101). At the same time, she emphasises how all forms of visual communication have undergone change: for example, she reminds us about the fundamental change that has taken place since image production was the preserve of professionals, with reception processes occurring primarily in the private sphere. This situation has now been substantially reversed. Production has been privatised, while dissemination and reception have been globalised, so that images originally intended for a specific context - whether local, regional or national - are now expected to function in a variety of settings. As part of this development, images assume greater significance and impact, both independently and at the cost of text. As Müller puts it: "Visuals are seen, perceived and interpreted also in non-literate contexts" (Müller, 2008, p. 102). Additionally, because the textual component is often absent, the power of the image increases, as does the potential for misunderstanding. Hence, Müller points to dramatic examples and consequences such as those we saw in the clashes over the cartoons in 2006 and subsequent incidents.

In Müller's view, then, it is not sufficient to have skills in, and knowledge of, the production of visuals, as the producer of these images must also be familiar with the social system in which the image is presented. In German-speaking Europe, there is an ongoing and lively debate on visual and more general media competences. Here, visual competence is divided into different segments entitled, 'Perception Competence', 'Interpretation Competence', 'Production Competence' and 'Reception Competence'. These are analytic categories that Müller and her research group have developed, in which the analytic cycle can be used in investigations into how visual components can be constituted in various contexts such as education, a) at the personal level, b) as applied in different practical or production contexts, or c) as it is 'gestalted' at the systemic level in a social, cultural, ethical and political context. We interpret Müller's model as demonstrating that competence is expressed or manifested as educated life/action/reflec- 
tion on these three levels, which represents a much more far-reaching interpretation of the relationship between competence and Bildung.

Visual production covers the creation of all types of visual presentations from kindergarten drawings to works of art, as well as commercial, journalistic or political visual productions. Competence in visual perception concerns how individuals and groups see and explore images, while interpretative competence includes how the visual is perceived in different contexts and the possible significances of differences in perception. Competence in visual reception is related to cognitive and emotional reactions to visual impressions, all of which interact in a process. This interaction can be studied in teaching situations (in schools) or group situations (discussions following a film showing) or in the creation of visual productions (Easter table decorations or birthday invitations).

Agreeing with Müller, Lars Qvortrup (2004) believes that increasing complexity is one of society's major challenges. However, Qvortrup goes on to suggest a solution to the problem of complexity, namely the addition of a new complexity, which may be in the form of new knowledge. In contrast to Müller's four categories of competence, Qvortrup proposes a concept of 'reflective Bildung'. As a background to this, he establishes a reflection taxonomy that builds on our knowledge of the first, second, third and fourth orders.

First-order knowledge is the basic level that takes the form of skills and qualifications. In relation to visual Bildung, the qualification level consists of factual knowledge about visual media and technical skills in handling these, such as shooting films or cutting/ editing. Second-order knowledge arises when these qualifications become the object of reflective knowledge. This may include what Martin Scorsese calls 'visual literacy': one must, for example, know what panning is, how to do it and the effect it has (Scorsese, 2006). Qvortrup refers to the knowledge that arises when we are required to take relevant action in relation to a specific context as the definition of competence. This kind of knowledge has therefore incorporated a productive aspect that is absent from the teaching programmes of many visual studies. Art history, film and television studies seldom include students' own productions, since the move from oral communication to both a written and a visual form of communication calls for reflection, not only as regards the use of technology, but also in relation to how the message is presented. A competent level requires the performance of analyses and a critical re-working of the product, as well as the justification of these on ethical, aesthetic or political grounds.

However, this type of competence can also be subject to processes of reflective knowledge and can be applied in unexpected contexts; this is a creative knowledge level of the third order. In this case knowledge assumes the character of knowing where the limits of its application lie and what the possibilities of exceeding these limits are. The creative level that comprises a familiarity with knowledge systems can be realised through teaching that fosters independent and creative behaviour as far as choice of genres and forms of expression are concerned. Regarding these three points, it seems that Müller and Qvortrup agree on the dimensions of the issue in their descriptions of how reflectivity and competence are connected.

In Qvortrup's (2004) systematics there is also a fourth level of knowledge, which he describes as metasystemic knowledge. This leads him to problematise the assumptions for the knowledge contained within the knowledge system. From skills and qualifications as the first level, the degree of complexity increases to competencies, creativity 
and finally to culture as the acme. Bildung arises when one achieves recognition of the differences and relationships between the levels, and is capable of critically observing one's own position and that of other people in the transitions between the levels. Finally, it is beneficial to develop a reflective attitude in relation to the media culture in both local and transnational contexts (Fritze, Haugsbakk, \& Nordkvelle, 2004).

\section{Conclusion - the Need for a Visual and Reflective Bildung}

This article has considered various problems that surface when visual culture sets its stamp on contemporary education without any attempt being made to problematise the visual dimension of Bildung. We have adduced arguments to demonstrate that the concept of Bildung per se has come to rest upon the world of visual concepts; we contend that learning is closely connected with 'the visual'. We have also raised questions about the background to the history of ideas that has resulted in Bildung being equated with texts. We have hinted at the ways in which the alphabet and reading ability cannot prevent the necessary acknowledgement of the fundamental pragmatic potential of visuality for Bildung in the future. Reliance on English-speaking traditions, according to which 'everything' is associated with 'literacy', and the context of supranational education that ties learning to 'skills', 'competencies' and 'anticipated learning outcomes', exerts, in our view, a levelling effect on any discussion of the fundamental concept of Bildung within pedagogy. We have therefore endeavoured to explore how the anatomy of the concept appears from the perspective of systems theory, arguing that Bildung goes beyond mere qualifications. Drawing on insights from German media pedagogics we have suggested the potential contribution of competences in different fields; further, we have proposed that productive skills should have a much more prominent place in 'the picture'. In line with Lars Løvlie, among others, we believe that the image - and the visual as a sense apparatus, as well as a means of human expression - are more closely related to the world in which we live today. Associative openness is more in keeping with the hypertransformations required. The consequences are, in our view, an urgent need for a visual and reflective Bildung in a globalised age. However, we have also emphasised the inherent complexity, and, like W. J. T. Mitchell, our intention in the foregoing has been to present a problematised and differentiated understanding of images and new media between 'iconoclasm' and 'idolatry'.

\section{References}

Berg Eriksen, Trond (1995). Om bildets plass i historisk perspektiv. In Yvonne Fritze (Ed.), Utdanning uten ord? Bilder og bildemedier $i$ utdanning og forskning. Rapport fra Nordisk seminar på Lillehammer (pp. 3-12). Lillehammer: Høgskolen i Lillehammer.

Buhl, Mie, \& Flensborg, Ingerlise (2011). Visuel kulturpcedagogik. København: Hans Reitzels forlag.

Dannelsesutvalget for høyere utdanning. (2009). Kunnskap og dannelse foran et nytt århundre. Retrieved from http://www.uib.no/ua/artikler/2009/08/sluttdokument-fra-dannelsessutvalget

Drotner, Kirsten (2003). Medier og dannelse i en global verden. In Ivar Selmer-Olsen \& Svein Sando (Eds.) Mediebarndommen. Artikkelsamling basert på en konferanse i Trondheim 27.-28. mars 2003 (pp. 6-10), Trondheim: Dronning Mauds Minne, Høgskole for førskolelærerutdanning.

Elf, Nikolaj Frydensbjerg (2009). Towards semiocy? Exploring a new rationale for teaching modes and media of Hans Christian Andersen fairytales in four commercial upper-secondary "Danish" classes. Odense: University of Southern Denmark. 
Elkins, James (2008). Introduction: The concept of visual literacy and its limitations. In James Elkins (Ed.) Visual Literacy. New York: Routledge.

Engebretsen, Martin (2010). Innledning. Hvorfor og hvordan analyserer vi sammensatte tekster? In Martin Engebretsen (Ed.) Skrift/bilde/lyd. Analyse av sammensatte tekster (pp. 17-36). Kristiansand: Høyskoleforlaget.

Enghel, Florencia, \& Wilkins, Karin (2012). Mobilizing communication globally. For what and for whom? Nordicom Review, 33, Special Issue, 9-14.

Erstad, Ola (2005). Digital kompetanse i skolen - en innføring. Oslo: Universitetsforlaget.

Fritze, Yvonne, Haugsbakk, Geir, \& Nordkvelle, Yngve (2004). Tema: Mediepedagogikk. Norsk medietidsskrift, 11(3), 206-214.

Gundersen, Bjarne Riiser (2006). I Guds bilde. Morgenbladet 10 February. Retrieved from https://morgenbladet.no/2006/i guds bilde

Hagtvedt, Bernt (2009). Kunnskap og dannelse foran et nytt århundre. Høyere utdanning og forskning i Norge møter den globaliserte verden. In Inga Bostad, Terje André Arnøy, Odd Einar Dørum, Bernt Hagtvet, Berit Rokne, Anders Lindseth, Lars Løvlie, Roger Strand. (Eds.) Kunnskap og dannelse foran et nytt århundre. Retrieved from http://www.uib.no/ua/artikler/2009/08/sluttdokument-fra-dannelsessutvalget

Haugsbakk, Geir (2010). Digital skole på sviktende grunn - om nye muligheter og dilemmaer. Oslo: Gyldendal Akademisk.

Hertzberg, Anne Gitte (2003). I begynnelsen var ikke ordet. Tidsskrift for den Norske Legeforening. 56(7). Retrieved from http://tidsskriftet.no/lts-pdf/pdf2003/56-7.pdf

Hug, Theo (2011). Visual competence, media literacy and "new literacies" - Conceptual considerations in a plural discursive landscape. Seminar.net, 7(1). Retrieved from http://seminar.net/images/stories/ vol7-issue1/Hug-VisualCompetenceMediaLiteracyandNewLiteracies-ConceptualConsiderationsinaPluralDiscursiveLandscape.pdf

Hultqvist, Kenneth, \& Petersson, Kenneth (1995). Foucault. Namnet på en modern vetenskaplig och filosofisk problematik. Stockholm: HLS förlag.

ITU (Forsknings- og kompetansenettverk for IT i utdanningen). (2003). Digital kompetanse: fra 4. basisferdighet til digital dannelse. Oslo: ITU.

Jewitt, Carey (2008). Multimodality and literacy in school classrooms. Review of Research in Education, 32(1), 241-267.

Johnsen, Egil Børre (1997). Oppgavetekst og dannelse: artiumsstilens emner, formuleringer og forvaltning 1880-1991. Acta humaniora, 6. Oslo: Universitetsforlaget.

Kemp, Peter (2006). Verdensborgeren som pcedagogisk ideal. København: Hans Reitzels Forlag.

Kress, Gunther (2003). Literacy in the new media age. London: Routledge.

Liestøl, Gunnar (2006). Sammensatte tekster - sammensatt kompetanse, Nordic Journal of Digital Literacy, 2(4), 277-300. Retrieved from http://www.idunn.no/ts/dk/2006/04

Løvland, Anne (2007). På mange måtar. Samansette tekstar i skolen. Bergen: Fagbokforlaget.

Løvland, Anne (2011). På jakt etter svar og forståing. Samansette fagtekstar i skulen. Bergen: Fagbokforlaget. Løvlie, Lars (2002). The Promise of Bildung. Journal of Philosophy of Education, 36(2), 467-487.

Løvlie, Lars (2003). Teknokulturell danning. In Rune Slagstad, Ove Korsgaard, \& Lars Løvlie (Eds.) Dannelsens forvandlinger (pp. 347-427). Oslo: Pax.

Marrou, Henri Irénée (1956). A History of Education in Antiquity. London: Sheed and Ward.

McNamara, Andrew (1996). Words and Pictures in the Age of the Image: An Interview with W.J.T. Mitchell. Eyeline, 30, 16-21. Retrieved from http://eprints.qut.edu.au/4620/1/4620.pdf

Mitchell, William John Thomas (2005). What Do Pictures Want?: The Lives and Loves of Images. Chicago: University of Chicago Press.

Mitchell, William John Thomas (2010). Image. In William John Thomas Mitchell \& Mark Boris Nicola Hansen (Eds.) Critical terms for media studies (pp. 35-48). Chicago, IL: University of Chicago Press.

Mulvey, Laura (1999). Visual pleasure and narrative cinema. In Jessica Evans \& Stuart Hall (Eds.) Visual culture: The reader (pp. 381-389). London: Sage.

Müller, Marion G. (2007). What is visual communication? Past and future of an emerging field of communication research. Studies in Communication Sciences, 7(2), 7-34.

Müller, Marion G. (2008). Visual competence: A new paradigm for studying visuals in the social sciences? Visual Studies, 23(2), 101-112.

Myhre, Reidar (1967). Store pedagoger i egne skrifter I. Oldtiden og middelalderen. Oslo: Fabritius.

Nohl, Arnd-Michael (2007). A media education perspective. Cultures of media practice and "media-bildung". European Journal of Cultural Studies, 10(3), 415-419.

Odame, Helen Hambly, \& Oram, Natalie (2012). Teaching and learning communication process as community-based transdisciplinary inquiry. Nordicom Review, 33, Special Issue, 177-188.

Qvortrup, Lars (2004). Det vidende samfund - mysteriet om viden. København: Forlaget Unge Pædagoger. 
Schwebs, Ture (2009). "Klikk på bildet så skal du få se”. Elevenes sammensatte hypertekster. In Svein Østerud (Ed.) ENTER. Veien mot en IKT-didatikk (pp. 95-114). Oslo: Gyldendal.

Scorsese, Martin (2006). A conversation with Martin Scorsese: The importance of visual literacy. Video retrieved from http://www.edutopia.org/martin-scorsese-teaching-visual-literacy-video

Slot, Marie Falkesgaard (2007). Elevers brug af elektroniske læremidler i dansk. In Susanne V. Knudsen, Dagrun Skjelbred, \& Bente Aamotsbakken (Eds.) Tekst $i$ vekst. Teoretiske, historiske og analytiske perspektiver på pedagogiske teksten (pp. 197-208). Oslo: Novus.

Storsul, Tanja (2014). Deliberation or self-presentation? Young people, politics and social media. Nordicom Review, 35(2), 17-28.

Tønnessen, Elise Seip (Ed.) (2010). Sammensatte tekster. Barns tekstpraksis. Oslo: Universitetsforlaget.

Verdegem, Pieter \& Fuchs, Christian (2013). Towards a participatory, co-operative and sustainable information society? A critical analysis of Swedish ICT policy discourses. Nordicom Review, 34(2), 3-18.

Yates, Frances (1969). The art of memory. Harmondsworth: Peregrine books.

Østerud, Svein (2007). Krever medieutviklingen en ny dannelsestenkning? In Soilikki Vettenranta (Ed.) Mediedanning og mediepedagogikk. Fra digital begeistring til kritisk dømmekraft (pp. 34-61). Oslo: Gyldendal.

YVONNE FRITZE, Ph.D., Associate Professor, Lillehammer University College, yvonne. fritze@hil.no

GEIR HAUGSBAKK, Ph.D., Associate Professor, Lillehammer University College, geir. haugsbakk@hil.no

YNGVE NORDKVELLE, Professor, Lillehammer University College, yngve.nordkvelle@hil.no 